Document downloaded from:

http://hdl.handle.net/10251/103989

This paper must be cited as:

Companys Pascual, R.; Lario Esteban, FC.; Vicens Salort, E.; Poler, R.; Ortiz Bas, A. (2017). An Approach to the Industrial Organization Engineering Background in Spain. Lecture Notes in Management and Industrial Engineering. 11-23. doi:10.1007/978-3-31955889-9_2

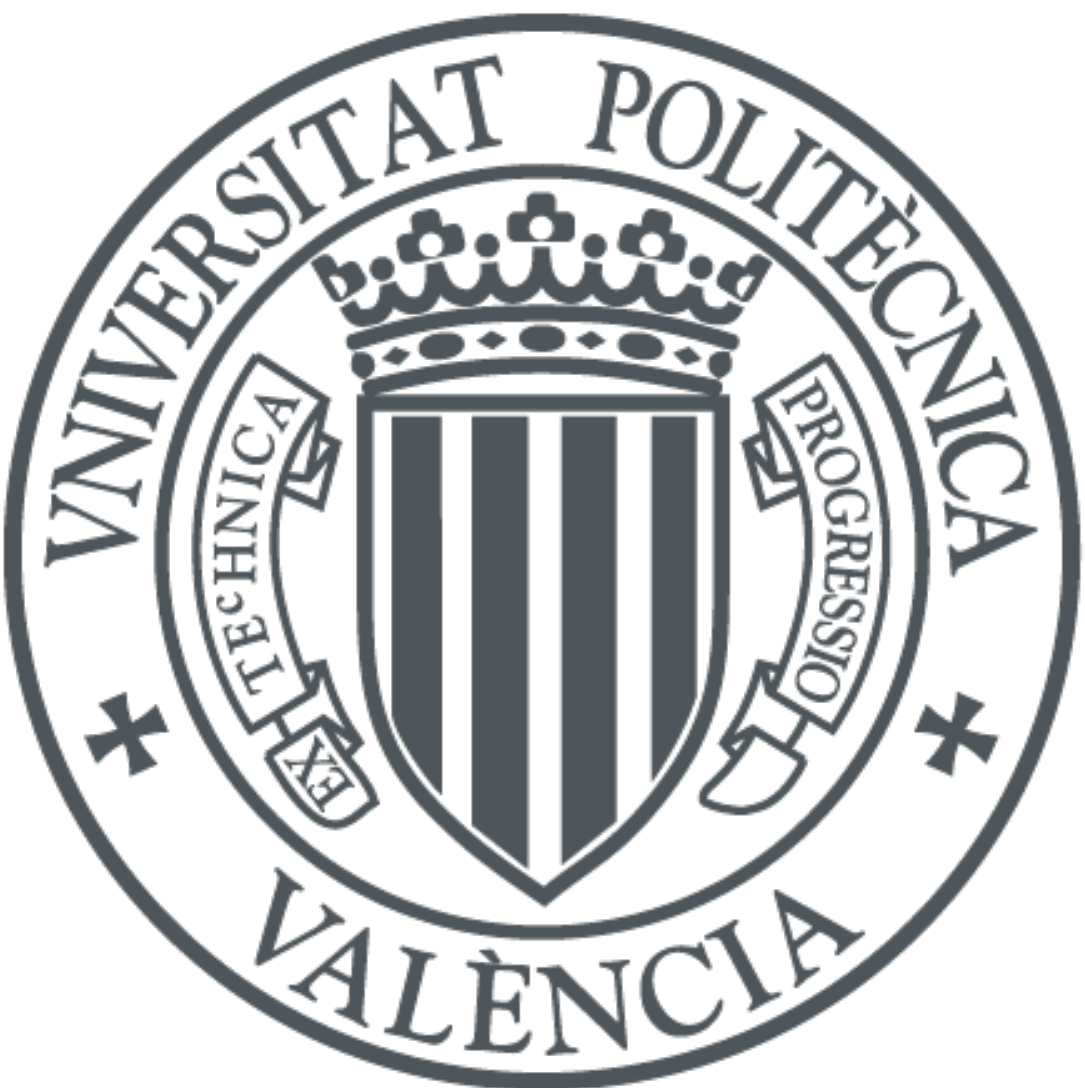

The final publication is available at

https://doi.org/10.1007/978-3-319-55889-9_2

Copyright Springer

Additional Information 


\title{
An Approach to the Industrial Organization Engineering Background in Spain
}

\author{
${ }^{1}$ Ramón Companys. (e-mail: ramon.companys@upc.edu) \\ Departament d' Organització d'Empreses, DOE - EPSEB - Universitat Politecnica de Catalunya, \\ BarcelonaTech, Gregorio Marañón 44-50, 3rd Floor, 08028 Barcelona, Spain \\ 2 Fco--Cruz Lario, Eduardo Vicens-Salort, Raúl Poler, Angel Ortiz (e-mail: fclario@cigip.upv.es, \\ evicens@cigip.upv .es, rpoler@cigip.upv .es, aortiz@cigip. upv.es) Research Centre on Production \\ Management and Engineering. Universitat Politeècnica de València. Camino de Vera, s/n, 46022 \\ Valencia, Spain
}

\begin{abstract}
The present article reviews the historie background of Spanish Industrial Engineering and brietly compares it with its equivalents in the USA and other countries, and indicates similarities and differences. The actions taken in Spain that have consolidated Organizational Engineering are presented, mainly in older Schools of Industrial Engineering, until the Industrial Organization speciality in the Degree in Industrial Engineering and in the Second Cycle of Industrial Organization Engineering carne into being, along with the impact that its adaptation to the European Higher Education Area (EHEA) has had with new Degrees, Master Degrees and Postgraduate Courses. Finally, a short section deals with the Organizational Engineering Development Association (ADINGOR), given its importance for the visibility and consolidation of Spanish Organizational Engineering in Spain and elsewhere.
\end{abstract}

Keywords. Industrial Organization Engineering, Industrial Engineering, University Degrees, Spain

\section{Industrial Engineering in Spain}

It is worth briefly reviewing the history of the relation between Spanish Industrial Organization Engineering and US Industrial Engineering.

Spanish Royal Decree, of 4 September 1850, created industrial teachings in Spain, along with the Degree in Industrial Engineering. During the presentation prior to the above Royal Decree, the then Spanish Minister of Trade, Training and Public Works stated:

"... that it was essential to create schools, among other relevant institutions, where students of industrial careers could receive the necessary training to excel in art, or to become perfect chemists, skilled mechanics, etc., is found .... "

"... Art. 59. Students ofthe higher school in the frrst section will receive first-class mechanical engineers. Those in the second section will receive frrst-class cbemical engineers. Those who study both degrees will receive industrial engineers."

Spanish Royal Order, of 24 March 1851, created the Schools of Industrial Engineering in Barcelona, Seville and Vergara (the one in Barcelona known as the "Barcelona Industrial School"), and that of 26 August 1851, created the School in Madrid known as the "Royal Industrial Institute", which was the only school able to teach higher levels. Between September and October 1851, these schools began to opérate in Barcelona, Madrid, Seville and Vergara. In 1855 and 1860, they opened in Gijón and Valencia, respectively. So university Industrial Engineering teachings in Spain began 165 years ago. 
A few years after these teachings carne into being, all the Industrial Schools in Spain closed, except for the one in Barcelona, due to an economic crisis. It was not unti1 32 years later that the Bilbao School opened as a continuation of the Vergara School. The Madrid School reopened 2 years later.

The Spanish Industrial Engineer was the result of combining the Mechanical Engineer and the Chemical Engineer. Electricity came later as a different activity to engineering. In 1864, Maxwell presented the Electromagnetic Theory, the first electric dynamo worked in Spain in 1874, and the first electric power station dates back to 1882 in New York. The creation of an Electricity branch in Spanish Industrial Engineering Studies was proposed in 1899, but was rejected.

Notwithstanding, a photograph exists which pictures a group of students during the 1899 Promotion, with a footnote that indicates Electromechanical Engineers (the grand-uncle ofthe eldest author took part in this promotion).

In order to suitably place the creation of the degree with other relevant events, it is worth indicating that the Ecóle Centrale de Paris (with which Industrial Engineering Schools share certain concomitances) was created in 1829. In 1848 the Barcelona-Mataró railway line was opened, which along with the MadridAranjuez one, were the first railway lines to operate in mainland Spain ${ }^{1}$. In 1854 the Battle of Balaclava took place during the Crimean War which witnessed one of the last cavalry charges, as featured in several films. Zurich Polytechnic was created in 1855, the same year that the Paris Universal Exhibition was held. In 1863 Meade defeated Lee in the battle ofGettysburg, which was the year when the London Underground opened.

Since its beginnings, not all Spanish Industrial Engineering training was technical. The Study Syllabus of the 1850 Royal Decree for higher levels reads, "Industrial Economy and Legislation: daily lesson", and this aspect is also found in the 1855 Royal Decree. A utopian view, no less, idyllically considered training at three levels (20 May 1855, Francisco de Luxan, the then Spanish Minister of Public Works and Transport, during the presentation prior to the Royal Decree, stated that):

"elementary schools where an honourable craftsman and hardworking apprentice in workshops, for art's sake, also acquire sure means to put into practice procedures and results ..."

"professional schools ... to offer expert operators and skilled builders to workshops and factories."

"preparation of industrial engineering ... has to produce teachers, skilful builders of machines, and learned directors of large-scale workshops and the biggest establishments ..."

This aspect was reinforced by the Moyano Law of 1857, which entrusted industrial engineers professional management tasks.

The Civil Service Decree of 18 September 1935, not abolished until the present day, which with the creation of Industrial Engineering attributions, indicated in its Preamble:

"the Industrial Engineer career ... has fully responded to the purpose for which it was

1 Before in 1837, a railway line worked in Cuba (Havana- Güines), and Cuba was Spain at that time. 
created ... training engineers so they acquire a solid scientific and technological basis that allows specialisation ... to provide our industry with ... competent managers."

Article 1 continues:

"this Decree ... confers [to the industrial engineers] the total capacity to plan, execute and direct all types of installations and works in the technical and industrial economy branches".

Article 2 reasserts:

"Industrial engineers are particularly capable of acting, conducting and leading all types of studies, works and organisms in the economic-industrial, statistical, social and occupational domain" .

All this evidences that, since it came into being, one of the key areas of the Industrial Engineer career lies in Management.

What is an Industrial Engineer? If we consider that Engineering is a creative profession, one interested in developing and applying scientific and technological knowledge to cover human society's requirements, in a context with physical, economic, human, political, legal and cultural limitations, then a series of consequences arises:

- This profession is not merely technical as it includes economic, human, political, legal and cultural factors.

- It is based on a body of basic knowledge that must mastered to be successful in one's profession.

- It is concerned about centring on the creation of products, processes and services that are useful to society.

- To be successful, an engineer needs to possess a series of skills and attitudes, which are essential for a triumphant career.

\section{Industrial Engineering in the USA and other countries}

Industrial Engineering appeared later in the USA than it did in Spain, but it is worth-while remembering its origins given its majar influence over the years. In 1886, H. R. Towne presented to the ASME (American Society of Mechanical Engineers) a communication entitled "The engineer as economist", which proposed that managing production plants was as important as managing their engineering. As a result of the works of Taylor (1856-1917) and of the Gilbreth spouses (1868-1924 and 1878-1972), a different engineering activity was undertaken at the Penn State University (USA) under the name of Industrial Engineering, with the first degrees taught in 1908, although the teaching of these studies extended more after World War II. Its core comprised the proposals of Frederick W. Taylor on Scientific Organization of Work. Nowadays more than 100 universities in the USA offer the Degree in Industrial Engineering.

Even though there are many points of contact between Spanish and US Industrial Engineers, there are also considerable differences, and the fact that names coincide creates considerable confusion. When translating "Industrial Engineering" into Spanish, it was necessary to adopt the term "Organización Industrial" whose literal translation into English ("Industrial Organization") has, more often than not, had 
its ambiguities. Certainly the other possibility, "Scientific Organization of Work", must appear over-pompous or restrictive as it refers to "Work".

In the USA, Industrial Engineering ("Ingeniería de Organización Industrial" in Spain) has become totally consolidated in both research and teaching terms: for over half a century, degrees of Industrial Engineer have proliferated in US Universities; they are increasingly important and more and more Industrial Engineering Centres and Departments appear; this development has taken place in parallel with, but without interfering with, Business Administration teaching and Departments.

Moreover, according to the "Engineering Education and Practice in the United States" report published in 1985 by the North American National Research Council, five main US Engineering branches exist: Electric/Electronic, Mechanical, Civil, Industrial (Organization) and Chemical.

Later Organizational Engineering, under the name "Industrial Engineering", has been implemented in other English-speaking countries like Canada and Australia, as "Industrial Engineering" done in Latin America. This branch of Engineering in Europe comes in various forms, but with a convergent approach: "Génie Industriel" inFrance; "Ingenieria Gestionale" in Italy; "Wirtschaftsingenieurwesen" in Germany and Austria. It is worth pointing out that in France, viewing an engineer as management is traditional (perhaps the original Hispano version was inspired by it). An example of such is Henry Fayol (1841-1925), a mining engineer who attended the École de Saint-Etienne. He studied a technical and management career in France and wrote the result of his reflections and experience in French. He was a pioneer in defining the tasks done in a company, identified the management task, and ensured that management to engineers could be, and indeed should be, taught.

\section{Spanish Industrial Engineering and Industrial Organization Engineering in the last 65 years}

In Plan 48 (1948) there was a single Chair in the Organizational Engineering domain, formally called the Chair Group and also known as "Economy, Organization and Legalization". This Chair embraced all the areas of "Theoretical and Applied Political Economy", and the "Spanish Economic Structure in relation to the World", "Industrial Administrative and Labour Law", "Industrial Psycho Techniques", "Occupational Health and Hygiene", "Business Economy and Production", and "Accountancy System Structuring of Industrial Companies".

After two entrance examinations, those students who passed studied a 6-year career. As part of this career, one part of year 5 and virtually all year 6 were destined to the subjects we know today as Industrial Organization, and were common to all branches, of which there were four in Barcelona: Mechanics, Electrics, Chemical and Textile. Some subjects taught in year 6 were "Methods Improvement", "Time Studying", "Health and Safety", "Statistical Quality Control", along with a series of subjects which today are included in Operations Management.

Madrid had Professors Castañeda Xerta and Sierra Andrés, while Barcelona had Professors De Orbaneja and Aragón. Bilbao had Professor Beascoechea Ariceta, 
while Terrassa had Professor Valero Vicente. Their later actions were to stand out in the creation of the Faculties of Economic Sciences of their corresponding universities; Professor Castañeda Xerta was named the first Dean of the Faculty of Economic Sciences at the Madrid Complutense University when this Faculty was created.

The Juan de la Cierva Board, whose objectives were Industrial Organization and Standardization, owed its promotion to Professor Fermín de la Sierra Andrés, a Professor of Economy at the Madrid ETSII Centre. He founded the Work Rationalization Institute (in charge of establishing studies and applications of the rational principies of improving productivity in industrial and technical areas) and he was its first Secretary in 1946; and the National Industrial Productivity Committee (in which all State organizations related with Economy participated), of which he was Secretary General.

In 1955, through the joint order of the Spanish Ministries of National Education and Industry, the Madrid Industrial Organization School was created to train profesional management staff in the Production Management and Business Management, undeniably the work of Professor de la Sierra, whose wish was a competitive Spanish industry of excellence at all levels.

In parallel, Professor De Orbaneja, a professor since 1943 at the School in Barcelona, created the "Escuela de Organización Industrial" (Industrial Organization School) in 1948 to teach Management studies in Catalonia, which acted as a platform to receive new knowledge in this area. This was the logical consequence of the Organization and Economy Seminar that created the Chair of "Economy, Organization and Legislation" at the Barcelona Higher Polytechnic School of Industrial Engineers in 1944. He was also the President of the National Committee of Industrial Productivity in Catalonia.

Professor Valero Vicente, Professor since 1948 ofthe Terrassa Higher Polytechnic School of Industrial Textile Engineers, in collaboration with RASA, and sponsored by the University of Navarre, the former Navarre General Studies, founded and was the first Director of the "Instituto de Estudios Superiores de la Empresa" (Higher Business Education Studies) (IESE). In 1964, he started his Master's Degree in Business Administration (MBA) in close contact with the Harvard Business School.

Meanwhile, Professor Beascoechea Ariceta, a Professor since 1960 at the Bilbao Higher Polytechnic School of Industrial Engineering, undertook a highly prolific activity in the R\&D area with more than 15 books and over 70 highly original and important articles published about: Models of Management, Products and Technology, Analysis of Companies, The Costs and Applications of Human Behaviour, among others. They were all key areas of Companies.

With the 1957 Plan, certain optional courses became specialities, which increased with Energy Techniques, one course was cut and the Economy Chair Group was divided into two: Economy and Administration. Administration became in charge of three areas: Production, Administration and Organization. Moreover, the Industrial Engineers Schools changed from Special Centres to Higher Technology Centres, while the former three (Madrid, Barcelona and Bilbao) changed to four as that of Terrassa was incorporated into the Industrial Engineers Schools. Plan 57 was shortlived and it is not exactly known what became of it, but the cuts in times were essentially to the detriment of Industrial Organization subjects. 
Notwithstanding, the 1950s proved fruitful for Industrial Organization. In Barcelona, Professor De Orbaneja created the "Instituto de Economía de la Empresa" (Business Administration Institute). In 1958, he founded the "Escuela de Administración de Empresas" (Business Management School) (BMS), similar to the "Escuela de Organización Industrial" in Madrid; the BMS had plenty of teachers who were also from the Engineers school and taught the Industrial Organization subjects ofthe subsequent Plan 64. One of the courses, which lasted 1 year, offered by the BMS in the 1960s was called "Mathematical Management Techniques", whose Dean was Professor Torrens-lbern. He never taught many students, but the subject continued nonstop for almost 20 years. There were also production management, personnel, commercial, administrative courses, etc., and even a computer studies one at the end of the 1960s, for which Professor Companys was Dean.

Professor Torrens-lbern had created the Special J. A. de Artigas Sanz Chair of Theoretical and Applied Statistics and the Applied Statistics and Operations Research Seminar. This Seminar and/or Special Chair ran courses and conferences, and took support in the BMS for "mailings" and in the School's Assembly Hall for meetings. At the end of the 1950s, Professor Kaufman gave an Operations Research course. In January 1964 Professors Torrens-lbern and Companys organised the Hispano-French Symposium of Modern Management Methods, which covered two basic themes: Investment Programming and Activity Programming.

According to Decree 3608/63 in December 1963, and with OECD's sponsorship, the Seville Higher Polytechnic School of Engineers reopened. In July 1965 the first visit of experts to this organization in Seville took place to deal with the new syllabus to be taught at this school. This special"OCDE" syllabus was approved in July 1967.

Works to start building began in August 1965, and teaching activities began in Pavilion L-1 a year later in September 1966. The School was officially opened in April 1967, and its first Head was José Ma de Amores Jiménez.

Then Plan 64 arrived with a 5-year cut instead of a 7-year one. Once again the new Administration Chair Group was divided into two: "Organization of Production" and "Business Administration". Specialities still included Energy Techniques, introduced into Plan 57 and, assumedly, to compensate the cuts made, we find the Industrial Organization speciality. What was considered at one time a success for Industrial Organization in Spain, could also be considered a reduction in broad Spanish Industrial Engineering knowledge, and core Industrial Organization subjects disappeared. It was at this time when Spanish Industrial Engineering moved away from American Industrial Engineering, except those who studied the Industrial Organization speciality.

The end result was that three Chair Groups came into being in the area of interest: Group XI "Economy" (in charge of areas of the Theory and Economic Structure, Business Management, Law and Psychosociology); Group XII "Administration" (Accounting, Costs and Budgets, Organization, Corporate Policy, Commercial Management and Information Integration); Group XIII "Organization of Production" (Organization of Production and Operations Research). To the above Higher Polytechnic Schools of Industrial Engineering, those of Valencia, Gijón, Valladolid, Vigo, Zaragoza, Málaga, Logroño, etc., were soon to join them. 
As a result of Plan 64, the "Instituto Politécnico de Valencia" (Valencia Polytechnic Institute) came into being (to later become the Polytechnic University of Valencia), with the Higher Technical School of Industrial Engineers at its heart, but with an experimental plan arranged into semesters (actually 4-month periods due to holiday periods). Since the very beginning, a Department of Industrial Organization carne into being, which comprised the four Chairs; their first professors were Professor Carot, Professor Dalmau, Professor De Miguel and Assistant Professor Lario.

In Valencia as of the 1980s and from the Business Organization Department, training activities were organised for professionals and Businesspeople in the Industrial Promotion Institute (IPI) of the Chamber of Commerce, Industry and Shipping in Project Planning, Statistical Quality Control, etc. In the 1990s, training activities were provided at Ford España S.L. in Almussafes (Valencia), which later became an MBA for Ford executives, sat jointly by Ford España, Anglia University and Polytechnic University of Valencia.

Halfway through the 1980s, and encouraged by Professor Nieto, the then Director of ETSII Valencia, the first MBA of a public Spanish university was set up, known as the Master in Economy and Industrial Business Management (MEGEI), which continued until 1992. It came into being to support the EGEI Association with its corresponding Board made up of businesspeople and representatives of public and private institutions. In order to train businesspeople and professionals with no university qualifications, the Valencia Club of Economy and Business Management (CEDE) and the Business Organization Department of the UPV launched the Master in Economy and Business Management (MEGE), which developed ten annual study programmes.

These actions taken by the Polytechnic Universities of Catalonia and Valencia, and the brief notes made of the Madrid Polytechnic University make us realise just how important teaching activities and technology transfer were in the Organizational Engineering domain since Plan 1948, and how they helped consolidate it and conferred it visibility as one of the main areas of Engineering.

\section{The Second Cycle of Industrial Organization Engineering Degree}

In 1992, after successive changes and amendments to the Syllabi of various Industrial Engineers Schools, the Degree in Industrial Organization Engineering (lOE) appeared as a second Cycle, as set out in Spanish Royal Decree 1401/1992, of 20 November (BOE no. 306, of 22 December 1992).

Its main objective was to train professionals capable of performing analyses, evaluations, designs and management in its four main approaches: Operations Management, Organizational Management, Economic Research and Strategic Management. Moreover, degree holders received relevant technological training in the areas of Automatics, Building, Electricity, Electronics, Mechanics, Chemistry, Environmental Technologies and Manufacturing Process Technologies.

The Degree in IOE prepared graduates to manage and direct production and services companies, and various types of public and prívate institutions (public administrations, Universities, NGOs, consultancy firms, etc.) and in all its areas: Project management, logistics, quality, costs, purchases, processes, production, 
products, commercial, finances, innovation and technology management, natural environment, human resources, etc. This dual technical and management training provided graduates with an overview of the company and its surroundings, so essential for improving the results of companies in any sector.

The Second Cycle Degree in IOE was taught in 27 Schools of 21 Spanish Universities. The difference between the Degree in IOE and other degrees was that it provided more knowledge about: Manufacturing Technologies, Production Organization and Management, Information Systems, Decision-Making Techniques, Modelling and Simulating Systems, Optimisation Techniques, Risk Assessments, etc.

We insist on differentiating the aspects of the Degree in IOE in organizational aspects and decision making in design, implementing and operating operational systems and services, such as integrating the above aspects into the technologies employed and the widespread use of models as a tool to analyse, make decisions and their practical guidance. All this results in the investigation of real business world problems, solved thanks to the so lid conceptual bases acquired.

\section{The Degree and the Master in Industrial Organization Engineering}

ANECA (2006) proposed creating a Degree in Industrial Organization Engineering (IOE) that did not exist in Spain. This name, however, did feature as a speciality in Industrial Engineering, created in 1964, even though the Second Cycle Degree in IOE came into being.

This proposal summarized the various models then cited in a Report, these being:

- A 4-year duration (240 ECTS) with an End-of-Career Project (ECP) in the $8^{\text {th }}$ semester

- The proposed Degree was to have a similar duration and structure to German Technical University Degrees, but with more Basic Sciences contents, like North American Industrial Engineers.

- This Degree was intended to prepare students to undertake their professions in a technical project and management domain, and to also offer a solid basis to those graduates who wished to do further studies to make an academic or scientific career.

On 14 March 2006, the External Experts Committee selected the degrees to be adapted to Europe, which included the Degree in IOE.

In 2008, ADINGOR (the Organizational Engineering Development Association) published the requirements to verify the "Degree in IOE". This document was forwarded to all Spanish University Rectors with Industrial Engineering Schools. It defined a minimum of credits in various blocks: Basic Training, Industrial Technologies, Information and Communication Technologies, Quantitative Methods and Organization of Production, Business Administration and Economic Engineering, the Industrial and Technological Area and End-of-Degree Project.

Nowadays in Spanish Universities, Organizational Engineering studies appear in both Undergraduate and Master Degrees. Undergraduate Degrees centre on general Industrial Organization Engineers training from both the Industrial Technologies and Industrial Organization perspectives. The objective of Master 
studies is to specialise on any of the main Industrial Organization Engineering approaches.

The principal objective of the Degree in IOE is to train graduates so they can analyse, model, design, implement and improve complex systems that comprise people, materials, money, information, machinery, technology and energy in order to offer products and services as soon as possible and with the best possible productivity, quality, reliability and efficiency. Graduates also receive technological training in the areas of automatics, building, electricity, electronics, mechanics, chemistry, environmental technologies and manufacturing process technologies.

The Degree in IOE is now offered in 22 Spanish Universities. Practically all the Universities that taught the Second Cycle of Industrial Organization have adopted the Degree and some new universities have appeared.

The Degree is arranged according to the Industrial Branch Pattern, with a first academic year studying Basic Sciences, a second studying Industrial Technologies, the third concentrates on Organizational Engineering, and the fourth academic year which, in some Schools, includes several blocks of optional courses.

The Master in IOE is being implemented less into Spanish Universities which, in some cases have considered it not all that necessary given the implementation of the Master in Industrial Engineering. We ought to remember that the main aim of Master Degrees is to specialise in any ofthe main Engineering approaches.

\section{The Organizational Engineering Development Association (ADINGOR)}

A fundamental role in launching and making Organizational Engineering visible in Spain has been played by ADINGOR. During the 3rd Organizational Engineering Congress held in September 1999, a meeting was organised to establish the "Organizational Engineering Development Association" (ADINGOR), during which its statutes were approved. This took place at the Barcelona Higher Polytechnic School of Industrial Engineers, attended to, and represented by fellow members of this School and those of Bilbao, Burgos, Gijón, Leganés, Madrid, Seville, Terrassa, Valencia, Valladolid, Vigo, etc. The proposal of the ADINGOR statutes was prepared by a group of developers from these Schools, who worked on the definition and consolidation of Organizational Engineering for several years.

A few years before, the Second Cycle Degree in Industrial Organization Engineering was approved. Its acceptance and implementation obtained several replies according to diverse Higher Technical Schools of Industrial Engineering and their corresponding Universities, even though they all implemented it. The result was that some teachers from the Business Organization area at the Higher Technical Schools of Industrial Engineering held several meetings to deal with the Business Organization knowledge area and the Industrial Organization Engineering because implementing this Degree was a priority as it was a service for society and Spanish industry. Reaching a consensus on the presence and actions of teachers from the Business Organization area at Higher Technical Schools of Industrial Engineering was essential to outline the Organizational Engineering profile.

From the very beginning, the need to not only characterise Industrial Organization Engineering appeared, as with other Engineering types, especially those in the 
Industrial branch (Electrics, Mechanics, Chemical, Electronic and Automatic Engineering, among others.), but also to identify relations of the Business Organization knowledge area with Organizational Engineering. Very quickly a consensus was reached that two professional and academic versions existed in the Business Organization area. The first was linked to business in general and was closely related to Business Administration and Management. The other focused more on the technology/company interface, especially industrial business (which clearly moved towards services with many physical and technology resources). In short Industrial Organization Engineering was conceived and identified with the technology/company interface, and paid a great deal of attention to Operations, but placed much priority on resources and technology in general, and on their efficient and efficacious use in particular.

An objective appeared naturally for ADINGOR, that of reinforcing and consolidating Organizational Engineering's own approach from Business Organization and Engineering. Much hard work was done on the content and scientific basis of this new field of knowledge, Organizational Engineering. The creation of a body of knowledge began, a conceptual body, but above all an applied and technological one that would allow a new Engineering field to be acknowledged, Organizational Engineering, by recognising its relation with and development from Industrial Engineering.

ADINGOR's Board of Directors agreed about certain actions to be taken, which were ratified by the General Assembly, so that the Organizational Engineering Knowledge Area would become visible and be acknowledged as such. The first step to take had to be the approval of this new Knowledge Area, "Organizational Engineering". Several Universities, including the Polytechnic Universities of Madrid and Valencia, approved it, while the Universities Council acknowledged it. And so it was that the Organizational Engineering Knowledge Area was established in several Universities, and more importantly, it was acknowledged by the Universities Council for these Universities.

Another of ADINGOR's main objectives was met: deciding on a point of encounter, a forum, where opinions, as well as academic and research experiences, could be exchanged, without forgetting the relational capital among group members. In short, making an organization (ADINGOR) available that represented the teachers and professionals who acknowledged themselves as belonging to "Organizational Engineering", and who promoted their yearly Congress, that of Organizational Engineering.

Another very important issue appeared, that of adapting the Undergraduate, Master and Postgraduate Degrees in Engineering to the European Higher Education Area, came about. In September 2003 during the Board of Directors meeting in Valladolid to hold CI0'03, the document about the proposal of a Degree in Industrial Organization Engineering was approved. The General Assembly delegated its review, improvement and definite preparation to the Board of Directors. Several informative meetings were organised with the successive Presidents of the Assembly of Directors from Higher Technical Schools of Industrial Engineers, the Conference of the Directors of University Schools of Industrial Technical Engineers and Polytechnic Schools, the Rectors of several Universities and the University Council Technical Teaching Sub-Committee members; they were explained the agreements reached during the General 
Assembly about the Degree in Industrial Organization Engineering. The majority offered their support and approval. This allowed a proposal of the IOE Syllabus structure to converge.

However, challenges were faced not only in relation to the Second Cycle, the new Organizational Engineering Knowledge Area and the Degree in Industrial Organization Engineering since CI0'06 held in Valencia. Following the agreements reached during the General Assembly, the successive Organising Committees continued to work on the internationalisation of both CIO and ADINGOR. The 2007 Congress in Madrid was also the $11^{\text {th }}$ Organizational Engineering Congress and the $1^{\text {st }}$ International Conference on Industrial and Management Engineering, while that 2008 one held in Burgos was the $12^{\text {th }} \mathrm{CIO}$ and the $2^{\text {nd }}$ International Conference on Industrial and Management Engineering. In both cases, the official languages were Spanish and English.

By making full use of the Madrid Congress, the Board ofDirectors held a meeting with top representatives of the Brazilian Production Engineering Association, ABEPRO, the equivalent to the Spanish Organizational Engineering. With the agreement ratified during the National Assembly, it was agreed to tighten relations with ABEPRO to collaborate in the call of joint congresses, and in publications and journals.

\section{Conclusions}

The present article has reviewed the relevant actions undertaken in Spanish Organizational Engineering activity, which has been similar to that of American Industrial Engineering in terms of the training, skills and competences of their professionals. The present work also indicates how Spanish Organizational Engineering has become consolidated through the Degree in Industrial Engineering (the Organization Engineering speciality), the Second Cycle of Industrial Organization Engineering and the current Degree in Industrial Organization Engineering and Master Degrees covering the Organizational Engineering field.

The actions undertaken by the first and successive Professors of the Chair Groups that stemmed from the initial "Economy, Organization and Legislation" ofthe Higher Technical School of Industrial Engineers, their graduates' professional activity, international publications and congresses, the visibility of R\&D\&I in this field, have all helped consolidate the Spanish Organization Engineering field.

\section{References}

ADINGOR (2008) Documento de Requisitos para la verificación del título de "Grado en Ingenieríade Organización Industrial". Boletín de la Asociación para el Desarrollo de la Ingeniería de Organización.

ANECA (2006) Libro Blanco. Título de Grado en Ing. de Organización Industrial.

Companys, R. (2001) La Organización Industrial en la ETSII. Congreso de Ingeniería de Organización. Sevilla.

Fons Boronat, J.M. (2001) La Ingeniería de Organización: Una visión desde la Admínistración de Empresas. Congreso de Ingeniería de Organización. Sevilla. 
Mula, J., Díaz Madroñero, M., Poler, R. (2011) Configuración del Grado en Ingeniería de Organización Industrial en las universidades españolas. 